\title{
Pre-sowing Seed treatments of Chemical, Electric, Magnetic and Botanical Treatments on Plant Growth, Yield and Yield Attributing Traits of Cluster Bean [Cyamopsis tetragonoloba (L.) Taub] [Variety Pusanavbahar]
}

\author{
Karunakar Reddy Guduri*, Prashant Kumar Rai and Nuthalapati Karthik
}

Department of Genetics and Plant Breeding, Naini Agricultural Institute, Sam Higginbottom University of Agriculture, Technology and Sciences, Prayagraj, 211007 U. P., India

*Corresponding author

Keywords

Cluster bean, Magnetic, Electric,

Panchagavya, Agniastra, $\mathrm{KNO}_{3}$

Article Info

Accepted:

17 January 2021

Available Online:

10 February 2021
The experiment was carried out by in the postgraduate Seed Testing Laboratory and field, Department of Genetics and Plant Breeding, Sam Higgin bottom University of Agriculture, Technology and Sciences, Prayagraj (U.P.) during Kharif season 20182019, to standardize the suitable pre-sowing seed treatment of Cluster bean (Pusanavbahar). Different concentration with different duration of pre-sowing seed treatments with control (Unhardened) were evaluated by screening 8 hour viz., Magnetic field (100mT for $45 \mathrm{~min}, 35 \mathrm{~min}$ and $25 \mathrm{~min}$ ), Electric treatment (70 mA @ 10min and $20 \mathrm{~mA} @ 5 \mathrm{~min}$ ), Panchagavya (3\% and 5\% for 8hrs), Agniastra (3\% and $5 \%$ for $8 \mathrm{hrs}), \mathrm{KNO}_{3}(3 \%, 5 \%$ and $7 \%$ for $8 \mathrm{hrs})$. It has been reported that all the presowing seed treatments showed significant. The variance with the control, in field highest field emergence percentage and yield and yielding attributes in $\mathrm{KNO}_{3}(5 \%$ for $8 \mathrm{hrs}$ ) has performed the best results in field parameters like Field emergence percentage, Plant height 90 DAS, Days to 50\% flowering, Number of clusters per plant, Number of pods per plant, Days to maturity, Pod weight per plant (g), Seed yield per plant (g), Seed yield per plot (g), Biological yield (g) and Harvest index (\%) followed by Magnetic field (100 $\mathrm{mT}$ for $35 \mathrm{~min}$ ) and Electric treatment (20mA for 5 min) and found to be lowest in control seeds. Hence seed treatment of Cluster bean seeds with $\mathrm{KNO}_{3} 5 \%$ is the best treatment compared to electric and other pre-sowing seed treatments.

\section{Introduction}

Cluster bean [Cyamopsis tetragonaloba (L.) Taub] Chromosome number $(2 \mathrm{n}=14)$ belongs to the family Fabaceae. It is assumed to have developed from the African species
Cyamopsis senegalensis. It is hardy and drought tolerant crop having deep root system which enables to utilize the available moisture more efficiently and offers to sustain under rainfed situation (Kherwat et al., 2013). In India, Cluster bean mostly grown in Rajastan, 
Haryana, Punjab, UttarPradesh and MadyaPradesh. Rajastan occupies first position in india both in area and production.

It accounts for almost 82.1 percent area and $70 \%$ production in India. Haryana and Gujarat has Second and Third position respectively. Rajastan has an area of 30 lakh hectare, Production of 15.46 lakh tones with a productivity of $515 \mathrm{~kg} / \mathrm{ha}$. (Anonymous 201314).Guar occupies an important role in Indian economy because of its industrial importance mainly due to the presence of gum in its endosperm (35 to $40 \%$ ). It had been grown since ancient era for various purposes viz., vegetable, green fodder, manure and feed. Green and tender pods of cluster bean are being used as a favourite vegetable in many parts of the counry. It is also grown as a forage crop (Ayub et al., 2012). The pods of cluster bean are as rich in food value as that of French bean.

Cluster bean can be used for multiple purposes (vegetable, cattle feed/fodder or green manure). It is a good source of nutrition and its tender green pods are also a cheap source of nutrients. Further cluster bean meal and seed are used as high protein cattle feed (Rai and Dharmatti, 2013). It is mainly cultivated for guar gum production and for forage, whereas in South India it is being cultivated for vegetable purpose (Tripathy and Das, 2013).

Cluster bean has several health benefits in both vegetable and powder form (guar gum). Guar gum has also been shown to be useful in weight loss and diabetes treatment. Guar pods are rich in soluble dietary fibre and lowers blood cholesterol levels. Guar gu $\mathrm{m}$ is a common ingredient in fibre-rich drinks marketed as health drinks and weight-loss drinks. Low in calories, the cluster bean (guar) contains vitamin $\mathrm{C}$, vitamin $\mathrm{K}$, vitamin $\mathrm{A}$, dietary fibre, folate, iron, manganese and potassium. The vitamin $\mathrm{K}$ is important for maintaining strong bones and proper development of foetus. The nutritional values per $100 \mathrm{gm}$ of raw cluster bean is one of the most important and potential vegetable cum industrial crop grown for its tender 2 pods for vegetable purpose and for endospermic gum (30-35\%)(Kumar and Singh, 2002).

Cluster bean grown as forage as well for extraction of guar gum (galactomannan) which finds its utilization in food industry, a substitute of fat in human food, paper, pharmaceutical, petroleum and cosmetic industry (Sortino and Gresta, 2007). After gum extraction, the residue called guar meal is used a high protein concentrate for animals.

The intercropping of cereal forages with forage legumes such as cluster bean has been found effective in increasing not only forage yield but also the quality of mixed forage especially protein contents (Ahmad et al., 2007).

Pre-sowing treatments of their seeds for ensuring their earlier, successful germination. This will help people to minimize their production cost of seedlings on a broad scale. A considerable body of evidences suggests that pre-sowing treatments strongly enhance the germination process (Hossain et al., 2005). Seeds of many species do not germinate well unless they are exposed to certain conditions. This state of not germinating unless the required conditions are met is called dormancy.

In the natural environment the conditions may be exposure to fire or being eaten by animals. When seeds are eaten they are exposed to the hydrochloric acid in the stomach of the animal, and this breaks the dormancy without damaging the seed. Similar methods are used by man to treat seeds and break the dormancy of seeds he wishes to germinate. 
Electro-magnetic treatment in whichexposure of seeds to electromagnetic fields is one of the safest and potential physical pre-sowing treatments to enhance the post germination development and crop stand (Florez et al., 2007).

\section{Materials and Methods}

The Research work was carried out at experimental field during Kharif season 20192020. Department of Genetics and plant breeding, Naini Agricuulture Institute, Sam Higgin bottom University of Agriculture, Technology and Sciences, Prayagraj (U.P). The statistical designs were applied carried out with Randomised Block Design (RBD) With 13 treatments and 3 replications. Seed material consists of Cluster bean Pusanavbahar. The treatments were represented as $\mathrm{T}_{0}-$ Control, $\mathrm{T}_{1}$ - Magnetic Treatment (100 MT) @ 45 minutes, $\mathrm{T}_{2}-$ Magnetic Treatment (100 MT) @ 35 minutes, $\mathrm{T}_{3}$ - Magnetic Treatment (100 MT)@25 minutes, $\mathrm{T}_{4}$ - Electric Treatment (70 mA) @ 10 minutes, $\mathrm{T}_{5}$ - Electric Treatment (20 mA) @ 5 minutes, $\mathrm{T}_{6}-$ Panchagavya@3\%,T 1 -Panchagavya@5\%, $\mathrm{T}_{8}$-Agniastra@3\%, T 9 - Agniastra@5\%, $\mathrm{T}_{10}-\mathrm{KNO}_{3} @ 3 \%, \mathrm{~T}_{11}-\mathrm{KNO}_{3} @ 5 \%, \mathrm{~T}_{12}-$ $\mathrm{KNO}_{3} @ 7 \%$.

\section{Method of magnetic field}

An electromagnetic field generator "Testron EM-20" with variable static magnetic field (SMF) strength (50 to $500 \mathrm{MT}$ ) with a gap of $5 \mathrm{~cm}$ between pole pieces was fabricated. A D.C. power supply (80V/10A) with continuously variable output current was used for the electromagnet.

A digital gauss meter model DGM-30 operating on the principle of Hall Effect monitored the field strength produced in the pole gap. The probe is made of Indium arsenide crystal and is encapsulated to a non- magnetic sheet of $5 \mathrm{~mm} \times 4 \mathrm{~mm} \times 1 \mathrm{~mm}$ and could measure 0-2 Tesla with full-scale range in increments of $5 \mathrm{MT}$. By regulating the current in the coils, desired strength of SMF was monitored, which was measured by a Gauss meter. The strength and duration was standardized for maximum enhancement of germination and vigour of seeds.

\section{Method of electric field}

To expose the seeds to electric field, an electric field generator was fabricated by using sodium chloride as electrolyte with copper $(+)$ and zinc (-) electrodes. A battery of $24 \mathrm{~V}$ DC was used as the power source for the electrolysis treatment of cluster bean seeds. The two electrodes were placed vertically inside the plastic tray parallel to each other. In the plastic tray seed material were placed in already prepared electrolyte solution lies below the level of electric cord connecting point. Electric power cods were connected with power supply unit in respective places. An electric current of DC $24 \mathrm{~V}$ was passed at required intensities for different duration as per the treatment through the seeds to serve electrotherapy treatment.

\section{Seeds soaking in solution}

After preparation of solution of Panchagavya, Agniastra and $\mathrm{KNO}_{3}$, clusterbean seeds were soaked in required solution for $8 \mathrm{hrs}$ at $25^{\circ} \mathrm{C}$ temperature. Untreated seed is called as control. After $8 \mathrm{hrs}$ of soaking the solution were drained out from the beaker and presoaked were air dried to original weight. After seed treatments seed were sown in field for occurring field observation.

\section{Design}

Randomized Block Design (RBD) Panse and Sukhatme, (1967)with three replications. Observations on Field viz- Field emergence, 
Plant height, and nodulation. The data was collected and statistically analyzed using ANOVA.

\section{Results and Discussion}

According to the findings, all the characteristics analyzed were influenced by the treatment and the difference between control (non-primed seeds) and primed seeds in Table-2 was entirely relevant.

\section{Analysis of variance}

The variance analysis presented in Table 1 for growth, seed yield, and yielding attributes. Analysis of variance showed that the variations between 13 treatments were important for characters that attribute growth and yield, viz. Percentage of field emergence, days to $50 \%$ flowering, days to maturity, plant height, number of clusters per plant, number of pods per plant, pod weight per plant, yield of seeds per plant, yield of seeds per plot, biological yield and index of harvest.

\section{Mean performance}

Mean value is defined by the ratio of the sum of the observations to the total number of observations. On other hand, the range is the simplest measurement in mathematical calculation and simple to understand. It avoids variation of overall data and depends only on extreme values. The data presented in Table 2 shows the mean performance of 13 treatments for 11 growths, yield, and yielding attributes. The grand mean for all the traits is also depicted in Table 2. Pre-sowing seed treatment with maximum percentage of field emergence $\left(88.00 \%\right.$ ) was highest in $\mathrm{T}_{11}-\mathrm{KNO}_{3}$ @ 5\% followed by $_{2-}$ Magnetic treatment (MT 100) @ 35 minutes (87.00\%) and found to be lowest in $_{0^{-}}$Control (78.33\%). The influence of pre-sowing seed treatment on the percentage of field emergence was found to be an important and comparable finding observed by Fiszer et al., (2004); Hirota et al., (1999) and Patil et al., (2012).

Maximum days taken to $50 \%$ flowering at flowering stage (34 days) was highest in $\mathrm{T}_{11^{-}}$ $\mathrm{KNO}_{3} @ 5 \%$ followed byT $2^{-}$Magnetic treatment (MT 100)@35 minutes (36 days) and found to be lowest inT $_{0^{-}}$Control (46 days)The impact of pre-sowing seed treatment on days with a flowering rate of 50 percent was found to be important and similar. Aleman et al., (2014) and Sarmadi et al., (2014).

Maximum days to taken maturity (103.33) was highest in $\mathrm{T}_{11^{-}} \mathrm{KNO}_{3} @ 5 \%$ followed by $_{2}$ - Magnetic treatment (MT 100) @ 35 minutes (104.67) and found to be lowest in $\mathrm{T}_{0^{-}}$ Control (117.33). The impact of treatment with pre-sowing seeds on days to maturity was found to be significant and similar finding observed by Moreón et al., (2007); Hunt et al., (2009); Ali et al., (2011).

Maximum Plant height at harvesting stage $(103.20 \mathrm{~cm})$ was highest in $\mathrm{T}_{11}-\mathrm{KNO}_{3} @ 5 \%$ followed by $\mathrm{T}_{2}$ - Magnetic treatment (MT 100) @ 35 minutes $(99.63 \mathrm{~cm})$ and found to be lowest in $\mathrm{T}_{0^{-}}$Control $(71.60 \mathrm{~cm})$.

The impact of treatment with pre-sowing seeds on days to maturity was found to be significant and similar finding observed by Vazirimehr et al., (2014); Mariappan et al., (2013); Flórez et al., (2012); Galland and Pazur, (2005)

Number of clusters per plant(13.86) was highest in $\mathrm{T}_{11^{-}} \mathrm{KNO}_{3} @ 5 \%$ followed by $\mathrm{T}_{2-}$ Magnetic treatment (MT 100) @ 35 minutes (13.80) and found to be lowest in $\mathrm{T}_{0^{-}}$Control (8.53). The impact of treatment with presowing seeds on days to maturity was found to be significant and similar finding observed by Ali et al., (2011) and Somasundaram et al., 
(2008). Number of pods per plant (81.50) was highest in $\mathrm{T}_{11}-\mathrm{KNO}_{3} @ 5 \%$ followed by $\mathrm{T}_{6-}$ Panchgavya@3\% (79.70) and found to be lowest in $\mathrm{T}_{0^{-}}$Control (56.13). The impact of treatment with pre-sowing seeds on days to maturity was found to be significant and similar finding observed by Mehri (2015); Podleoeny et al., (2004).

Pods weight per plant (41.10 g) was highest in $\mathrm{T}_{11}-\mathrm{KNO}_{3} @ 5 \%$ followed by $\mathrm{T}_{2}$ - Magnetic treatment (MT 100) @ 35 minutes (40.30 g) and found to be lowest in $\mathrm{T}_{0^{-}}$Control (28.83 $\mathrm{g})$. It was found that the effect of pre-sowing seed treatment on the number of seeds per pod was important and similar to the findings observed by Sarmadi et al.,(2014); Shine M.B. (2011); Pietruszewski S. (2002).

Maximum seed yield per plant and seed yield per plot $(10.12 \mathrm{~g}$ and $446.10 \mathrm{~g})$ respectively were highest in $\mathrm{T}_{11}-\mathrm{KNO}_{3} @ 5 \%$ followed by $_{2-}$ Magnetic treatment (MT 100) @ 35 minutes $(9.61 \mathrm{~g}$ and $412.60 \mathrm{~g})$ respectively and found to be lowest in $\mathrm{T}_{0^{-}} \operatorname{Control}(5.80 \mathrm{~g}$ and $181.40 \mathrm{~g}$ ) respectively. It was found that the effect of pre-sowing seed treatment on the number of seeds per pod was important and similar to the findings observed by Johnson et al., (2005); Pietruszewski and Wójcik (2000); Simi et al., (2013).

Biological yield (1505.97 g) was observed highest in $\mathrm{T}_{11^{-}}-\mathrm{KNO}_{3} @ 5 \%$ followed by $\mathrm{T}^{-}$ Magnetic treatment (MT 100) @ 35 minutes $(1463.62 \mathrm{~g})$ and found to be lowest in $\mathrm{T}_{0^{-}}$ Control (793.85 g). It was found that the effect of pre-sowing seed treatment on the number of seeds per pod was important and similar to the findings observed by Schwinn, F. (2014); Iqbal et al., (2012); Martinez et al., (2000); Dalal et al., (2014).

Harvest index(29.61\%) was observed highest in $\mathrm{T}_{11}-\mathrm{KNO}_{3} @ 5 \%$ followed by $\mathrm{T}_{2}$ - Magnetic treatment (MT 100) @ 35 minutes (28.17\%) and found to be lowest in $\mathrm{T}_{0^{-}}$ Control(22.84\%). It was found that the effect of pre-sowing seed treatment on the number of seeds per pod was important and similar to the findings observed by Farooq et al., (2012); Vashisth and Nagarajan (2008); Shashurin et al., (2014).

\section{Summary}

Significant differences in all the field observations were observed due to the environmental effect on the different treatment of cluster bean bean. The significantly maximum percentage of field emergence $(88.00 \%)$ was highest in $\mathrm{T}_{11}-\mathrm{KNO}_{3} @ 5 \%$ followed by $_{2}$ - Magnetic treatment (MT 100) @ 35 minutes $(87.00 \%)$ and found to be lowest in $\mathrm{T}_{0^{-}}$Control (78.33\%). Plant height at harvesting stage $(103.20 \mathrm{~cm})$ was highest in $\mathrm{T}_{11^{-}} \mathrm{KNO}_{3} @ 5 \%$ followed by $\mathrm{T}_{2}$ - Magnetic treatment (MT 100) @ 35 minutes $(99.63 \mathrm{~cm})$ and found to be lowest in $\mathrm{T}_{0^{-}}$Control (71.60 $\mathrm{cm})$.Days to $50 \%$ flowering at flowering stage (34 days) was highest in $\mathrm{T}_{11^{-}}-\mathrm{KNO}_{3} @ 5 \%$ followed by $\mathrm{T}_{2}$ - Magnetic treatment (MT 100) @ 35 minutes (36 days) and found to be lowest in $_{0^{-}}$Control (46 days) Number of clusters per plant(13.86) was highest in $\mathrm{T}_{11^{-}}$ $\mathrm{KNO}_{3} @ 5 \%$ followed byT $2^{-}$Magnetic treatment (MT 100) @ 35 minutes (13.80) and found to be lowest $\mathrm{inT}_{0^{-}}$Control (8.53).

Number of pods per plant (81.50) was highest in $\mathrm{T}_{11^{-}} \quad \mathrm{KNO}_{3}$ @ $5 \%$ followed by $\mathrm{T}_{6^{-}}$ Panchgavya@3\% (79.70) and found to be lowest in $\mathrm{T}_{0^{-}}$Control (56.13). Days to maturity (103.33) was highest in $\mathrm{T}_{11}-\mathrm{KNO}_{3}$ @ 5\% followed by $\mathrm{T}_{2}$ - Magnetic treatment (MT 100)@35 minutes (104.67) and found to be lowest in $_{0^{-}}$Control (117.33).Pods weight per plant $(41.10 \mathrm{~g})$ was highest in $\mathrm{T}_{11}-\mathrm{KNO}_{3}$ @ 5\% followed by $\mathrm{b}_{2}$ - Magnetic treatment (MT 100)@ 35 minutes(40.30 g) and found to be lowest in $\mathrm{T}_{0^{-}}$Control $(28.83 \mathrm{~g})$. 
Table.1 Analysis of variance for 11 characters of growth and yield in cluster bean

\begin{tabular}{|c|c|c|c|c|}
\hline \multirow{2}{*}{ S.No. } & Characters & \multicolumn{3}{|c|}{ Mean sum of square } \\
\cline { 3 - 5 } & & $\begin{array}{c}\text { Replications } \\
(\mathbf{d f =})\end{array}$ & $\begin{array}{c}\text { Treatments } \\
(\mathbf{d f}=\mathbf{1 2})\end{array}$ & $\begin{array}{c}\text { Error } \\
(\mathbf{d f}=\mathbf{2 4})\end{array}$ \\
\hline $\mathbf{1 .}$ & Field Emergence Percentage & 3.18 & $29.81^{*}$ & $\mathbf{4 . 1 0}$ \\
\hline $\mathbf{2 .}$ & Plant height (cm) & 15.91 & $276.52^{*}$ & $\mathbf{8 . 4 1}$ \\
\hline $\mathbf{3 .}$ & Days to 50\% flowering & 1.33 & $34.32^{*}$ & $\mathbf{5 . 1 9}$ \\
\hline $\mathbf{4 .}$ & Number of clusters per plant & 2.22 & $10.66^{*}$ & $\mathbf{0 . 7 7}$ \\
\hline $\mathbf{5 .}$ & Number of pods per plant & 34.33 & $276.42^{*}$ & $\mathbf{1 0 . 7 1}$ \\
\hline $\mathbf{6 .}$ & Days to maturity & 22.26 & $61.45^{*}$ & $\mathbf{1 0 . 8 1}$ \\
\hline $\mathbf{7 .}$ & Pods weight per plant & 28.48 & $47.61^{*}$ & $\mathbf{8 . 7 4}$ \\
\hline $\mathbf{8 .}$ & Seed yield per plant $(\mathrm{g})$ & 0.27 & $5.72^{*}$ & $\mathbf{0 . 3 2}$ \\
\hline $\mathbf{9 .}$ & Seed yield per plot (g) & 18846.81 & $21945.68^{*}$ & $\mathbf{1 0 1 8 . 1 5}$ \\
\hline $\mathbf{1 0}$ & Biological yield $(\mathrm{g})$ & 260957.17 & $168987.73^{*}$ & $\mathbf{1 3 5 1 5 . 6 9}$ \\
\hline $\mathbf{1 1 .}$ & Harvest index & $\mathbf{7 . 5 9}$ & $\mathbf{1 3 . 3 6}$ & $\mathbf{1 . 0 7}$ \\
\hline
\end{tabular}

Table.2 Mean performance of cluster bean for growth, yield and yield attributing characters of Clusterbean

\begin{tabular}{|c|c|c|c|c|c|c|c|c|c|c|c|}
\hline Treatments & $\begin{array}{c}\text { Field } \\
\text { Emergence } \\
\text { Percentage }\end{array}$ & $\begin{array}{l}\text { Plant } \\
\text { Height } \\
\text { (cm) }\end{array}$ & \begin{tabular}{|c|} 
Days to \\
$50 \%$ \\
Flowering
\end{tabular} & $\begin{array}{c}\text { Number of } \\
\text { Clusters } \\
\text { per Plant }\end{array}$ & $\begin{array}{c}\text { Number of } \\
\text { Pods per } \\
\text { Plant }\end{array}$ & $\begin{array}{r}\text { Days to } \\
\text { Maturity }\end{array}$ & $\begin{array}{c}\text { Pods } \\
\text { weight pe } \\
\text { plant }\end{array}$ & $\begin{array}{c}\text { Seed } \\
\text { yield per } \\
\text { plant } \\
(\mathrm{g})\end{array}$ & $\begin{array}{c}\text { Seed yield } \\
\text { per plot } \\
\text { (g) }\end{array}$ & $\begin{array}{c}\text { Biological } \\
\text { Yield } \\
\text { (g) }\end{array}$ & $\begin{array}{c}\text { Harvest } \\
\text { index } \\
(\%)\end{array}$ \\
\hline $\mathbf{T}_{0}$ & 78.33 & 71.60 & 45.33 & 8.53 & 56.13 & 117.33 & 28.83 & 5.80 & 181.40 & 27.84 & 20.83 \\
\hline$T_{1}$ & 80.00 & 72.07 & 43.33 & 9.73 & 58.50 & 115.55 & 30.73 & 6.39 & 190.77 & 29.34 & 21.74 \\
\hline $\mathbf{T}_{2}$ & 87.00 & 99.63 & 35.67 & 13.80 & 79.20 & 104.67 & 40.30 & 9.61 & 412.60 & 33.63 & 28.57 \\
\hline $\mathbf{T}_{3}$ & 83.67 & 87.00 & 39.67 & 10.20 & 60.80 & 111.33 & 35.27 & 7.88 & 297.03 & 30.73 & 25.63 \\
\hline $\mathbf{T}_{4}$ & 81.33 & 81.90 & 41.33 & 11.20 & 56.00 & 113.67 & 33.20 & 7.10 & 256.53 & 29.82 & 23.80 \\
\hline $\mathbf{T}_{5}$ & 79.00 & 76.20 & 44.67 & 9.00 & 54.23 & 116.33 & 31.67 & 6.02 & 210.47 & 26.48 & 22.73 \\
\hline$T_{6}$ & 86.33 & 92.17 & 37.33 & 13.13 & 79.70 & 106.67 & 39.13 & 9.21 & 388.93 & 32.23 & 28.57 \\
\hline $\mathbf{T}_{7}$ & 84.00 & 88.60 & 39.33 & 11.33 & 68.20 & 109.67 & 36.57 & 8.09 & 304.70 & 30.74 & 26.31 \\
\hline $\mathbf{T}_{8}$ & 82.67 & 85.10 & 40.67 & 10.80 & 65.13 & 112.33 & 35.03 & 7.44 & 286.60 & 29.76 & 25.00 \\
\hline $\mathbf{T}_{9}$ & 85.00 & 88.73 & 38.78 & 13.20 & 71.37 & 108.31 & 38.70 & 8.51 & 324.57 & 31.48 & 27.03 \\
\hline$T_{10}$ & 80.67 & 81.03 & 42.33 & 13.80 & 70.10 & 114.67 & 32.07 & 6.88 & 233.40 & 29.58 & 23.25 \\
\hline$T_{11}$ & 88.00 & 103.20 & 34.33 & 13.86 & 81.50 & 103.33 & 41.10 & 10.12 & 446.10 & 34.40 & 29.41 \\
\hline$T_{12}$ & 85.67 & 91.60 & 37.78 & 12.26 & 73.30 & 107.55 & 39.00 & 8.83 & 368.53 & 31.78 & 27.78 \\
\hline $\begin{array}{l}\text { Grand } \\
\text { Mean }\end{array}$ & 83.21 & 86.06 & 39.94 & 11.61 & 67.24 & 110.87 & 35.51 & 7.84 & 300.13 & 30.60 & 25.43 \\
\hline C.D. $(5 \%)$ & 4.73 & 4.11 & 3.84 & 1.47 & 5.52 & 5.54 & 4.98 & 0.74 & 12.20 & 2.77 & 2.79 \\
\hline SE(m) & 1.62 & 1.41 & 1.32 & 0.50 & 1.89 & 1.90 & 1.71 & 0.25 & 4.18 & 0.95 & 0.96 \\
\hline SE(d) & 2.29 & 1.99 & 1.86 & 0.71 & 2.67 & 2.68 & 2.41 & 0.36 & 5.91 & 1.34 & 1.36 \\
\hline C.V. & 3.37 & 2.83 & 5.71 & 7.54 & 4.87 & 2.98 & 8.33 & 5.63 & 2.41 & 5.36 & 6.46 \\
\hline
\end{tabular}


Significantly maximum seed yield per plant and seed yield per plot (10.12g and 446.10g) respectively were highest in $\mathrm{T}_{11}-\mathrm{KNO}_{3} @ 5 \%$ followed by $\mathrm{T}_{2}$ - Magnetic treatment (MT 100) @ 35 minutes (9.61 $\mathrm{g}$ and $412.60 \mathrm{~g})$ respectively and found to be lowest in $\mathrm{T}_{0^{-}}$ Control $(5.80 \mathrm{~g}$ and $181.40 \mathrm{~g})$ respectively. Biological yield (1505.97 g) was observed highest in $\mathrm{T}_{11^{-}} \mathrm{KNO}_{3} @ 5 \%$ followed by $\mathrm{T}_{2}$ Magnetic treatment (MT 100) @ 35 minutes (1463.62 $\mathrm{g}$ ) and found to be lowest in $\mathrm{T}_{0^{-}}$ Control (793.85 g). Harvest index $(29.61 \%)$ was observed highest in $\mathrm{T}_{11}-\mathrm{KNO}_{3} @ 5 \%$ followed by $_{2}$ - Magnetic treatment (MT 100) @ 35 minutes $(28.17 \%)$ and found to be lowest in $\mathrm{T}_{0^{-}}$Control (22.84\%).

Subsequent conclusions are drawn based on observations derived from the current experiment. The treatment of pre-sowing seeds increases the germinability and vigour of Cluster bean seeds, substantially in field conditions. Pre-sowing seed treatment with Potassium nitrate (5\% for 8 hours) followed by Magnetic treatment @ 100 MT (35 min), Electric treatment @ 20mA (5 min), Potassium nitrate (7\% for 8 hours) and Agniastra (5\% for 8 hours) significantly increase the Field emergence percentage, Plant height, Number of clusters per plant, Number of pods per plant, Pods weight per plant, Seed yield per plant and Seed yield per plot parameters of cluster bean (Pusanavbahar).

Pre-sowing seed treatment with $\mathrm{KNO}_{3}(5 \%$ for 8 hours) and Magnetic treatment @ 100mT (35 min) showed maximum increase in germinability and vigour of cluster bean seeds and found to be lowest in control seeds. Presowing seed treatment of the cluster bean seeds in which $\mathrm{KNO}_{3}$ best result to enhance germinability, vigour and quality parameters. These conclusions are based on the results of six months investigation and therefore further investigation is needed to arrive at valid recommendations.

\section{Acknowledgement}

The author sincere gratitude goes to all faculty members of Sam Higgin bottom University of Agriculture, Technology and Science Prayagraj, U.P., Department of Genetics and Plant Breeding, for providing all necessary facilities and support.

\section{References}

Ahmad, A.H., R. Ahmad, N. Ahmad and A. Tanveer, (2007). Performance of forage sorghum intercropped with forage legumes under different planting patterns. Pak. J. Bot., 39: 431439.

Aleman E.I., Moreira R.O., Lima A.A., Silva S.Ch., Gonzalez- Olmedo J.L., and Chalfun-Junior A., (2014).Effect of 60 $\mathrm{Hz}$ sinusoidal magnetic field on in vitro establishment multiplication and acclimatization phases of coffee Arabica seedling. Bioelectromagnetics, 35, 414-425.

Ali, M. N.; Ghatak, S.; Ragul, T. (2011). Biochemical analysis of Panchagavya and Sanjibani and their effect in crop yield and soil health. Journal of Crop and Weed 7(2): 84-86.

Anonymous, (2013-14). Vital Agriculture Statistics, State level summary of Principal crops in Rajasthan, Directorate of Agriculture, Jaipur, Pant Krishi Bhawan, Jaipur, Rajasthan. Molecular Biol., 2, 113-119.

Dalal, L. P1., Abhishek Mishra and Dhabarde, P. F. (2014). Growth Yield and Quality of Vegetables under Chemical and Organic Farming International Journal of Scientific \& Engineering Research, Volume 5, Issue 3: 1124-29.

Farooq, M., Wahid, A. and Siddique, K.H.M. (2012). Micro and Macronutrient application through seed treatments - a review. Journal of Soil Science and 
Plant Nutrition, 12(1): 125-142.

Fiszer G., Tausz M., and Gill D., (2004).Effect of weak $16^{2} / 3 \mathrm{~Hz}$ magnetic field on growth parameters of young sunflower and wheat seedling. Bioelectromagnetics, 25, 638-641.

Florez, M., Carbonell, M.V. and Martinez, E. (2007) Exposure of maize seeds to stationary magnetic fields: Effects on germination and early growth. Environmental and Experimental Botany journal. 59: 68-75.

Flórez M., Martinez E., and Carbonell M.V., (2012).Effect of magnetic field treatment on germination of medicinal plant. Pol. J. Environ. Stud., 21, 1 5763.

Galland P. and Pazur A., (2005). Magnetoreception in plants. J. Plant Res., 118, 371-389.

Hirota N.M., Nakagawa J., and Kitazawa K., (1999). Effect of magnetic field on the germination of plant. J. Appl. Physics, 85(8), 5717-5719.

Hunt R.W., Zavalin A., Bhatnagar A., Chinnasamy S., and Das K.C., (2009). Electromagnetic biostimulation of living cultures for biotechnology, biofuel and bioenergy application. Int. J. Molecular Sci., 10, 4515-4558.

Hossain MA, Arefin MK, Khan BM, Rahman MA (2005). Effects of Seed Treatments on Germination and Seedling Growth Attributes of Horitaki (Terminalia chebula Retz.) in the nursery. Research Journal of Agriculture and Biological Sciences. 1(2): 135-141.

IqbalM., Haq Z.U., Jamil Y., and Achmed M.R., (2012). Effect of pre-sowing magnetic treatment on properties of pea. Int. Agrophys., 26, 25-31.

Johnson SE, Lauren JG, Welch RM and Duxbury JM. (2005). A comparison of the effects of micronutrient seed priming and soil fertilization on the mineral nutrition of chickpea (Cicer arietinum), lentil (Lens culinaris), rice (Oryza sativa) and wheat (Triticum aestivum) in Nepal. Experimental Agriculture 41: 427-448.

Kumar, D. and Singh, N. B. (2002). Guar in India, Scientific publishers (India), Jodhpur, 225.

Moreón L.P., Castro Palacio J.C., Velázquez Abad L., and Govea A.P., (2007). Stimulation of Pinus tropicalis $\mathrm{M}$. seeds by magnetically treated water. Int. Agrophysics, 21, 173-177.

Mariappan, N., Srimathi, P., Sundaramoorthy, L. and Sudhakar, K. (2013). Influence of seed fortification treatment with inorganic nutrients in Jatropha curcas (L.). Journal of Energy Bioscience, 4(1): 1-6.

Mehri S. (2015). Effect of Seed Priming on Yield and Yield Components of Soybean. American-Eurasian Journal of Agricultural and Environmental Sciences 15: 399-403.

Martinez E., Carbonell M.V., and Amaya J.M., (2000). A static magnetic field of $125 \mathrm{mT}$ stimulates in initial growth stages of barley (Hordeum vulgare L.). Electro- and Magnetobiol., 19, 271277.

Panse V. G., and Sukhatme P. V. (1967). Statistical Methods for Agricultural Workers. Indian Council of Agricultural Research: Pp. 103-108.

Patil, S.V., Hiremath, S.M., Halikatti, S.I., M.N., Hebsur, Babalad. H.B., Sreenivasa, N.S. and Somangouda, G. (2012). Effect of organics on growth and yield of chickpea (Cicer arietinum L.) invertisols. Karnataka J. Agric. Sci., 25(3): 326-331.

Podlesni, J., Pietruszewski, S., Podlesna, A., (2004). Efficiency of the magnetic treatment of broad bean seeds cultivated under experimental plot conditions. Int. Agrophys. 18 (1), 65- 
71.

Pietruszewski, S. (2002). Influence of magnetic fields on seeds germination of selected cultivated plants (in Polish). Acta Sci. Pol., Technica Agraria, 1(1), 75-81.

Rai, P.S. and Dharmatti, P.R. (2013). Genetic divergence studies in cluster bean [Cyamopsis tetragonoloba (L.) Taub.]. Global J. Sci. Frontier Res. Agric. Vet. 13: 1-5.

Sarmadi, R., Asli, D. E. and Eghdami, A., (2014). Effect of seed priming by potassium nitrate on nodulation of common bean (Phaseolus vulgaris L). International Journal of Farming and Allied Sciences, ISSN (2322-4134): 312-316.

Somasundaram, E., N. Sankaran, S. Meena, T.M. Thiyagarajan, K. Chandaragiri and S. Panneerselvam. (2007). Response of greengram to varied levels of Panchagavya (organic nutrition) foliar spray. Madras Agriculture Journal, 90: 169-172.

Sortino, O. and F. Gresta, (2007). Growth and yield performance of five guar cultivars in a Mediterranean environment. Ital. J. Agron., 4: 359364.

Sarmadi, R., Asli, D. E. and Eghdami, A., (2014). Effect of seed priming by potassium nitrate on nodulation of common bean (Phaseolus vulgaris L). International Journal of Farming and Allied Sciences, ISSN (2322-4134):
312-316.

Shine, M.B. (2011). Biophysical and physiological changes in maize (Zea mays L. var. HQPM1) after pretreatment of seeds by magnetic field.

Simi T., Anjali A., Viswantham Ch., Anil D., and Sudipta B., (2013). Magnetopriming circumvents the effect of salinity stress in germination in chickpea. Acta Physiol. Plant., 35, 3401-341.

Schwinn, F. (2014). Seed treatment - a panacea for plant protection? Seed Treatment: Progress and Prospects. BCPC Publications. Monograph 57, 3.

Shashurin M.M., Prokopiev A.A., Shein G.V., Filippova G.V., and Zhuravskaya A.N. (2014). Physiological responses of Plantago media to electromagnetic field of power-line frequency $(50 \mathrm{~Hz})$. Russian J. Plant Physiol., 61, 4, 484 488.

Tripathy, S. and Das, M.K. (2013). Guar gum: present status and applications. $J$. Pharm. Scientific Innov. 2: 24-28.

Vashisth A. and Nagarajan S., (2008). Exposure of seeds to static magnetic field enhances germination and early growth characteristics in chickpea (Cicer arientinum L.). Bioelectromagnetics, 29, 571-578.

Vazirimehr MR, Ganjali HR, Rigi K and Keshtehgar A. (2014). Effect of seed priming on quantitative traits corn. International Journal of Plant Sciences 4: 134-140.

\section{How to cite this article:}

Karunakar Reddy Guduri, Prashant Kumar Rai and Nuthalapati Karthik. 2021. Pre-sowing Seed treatments of Chemical, Electric, Magnetic and Botanical Treatments on Plant Growth, Yield and Yield Attributing Traits of Cluster Bean [Cyamopsis tetragonoloba (L.) Taub] [Variety Pusanavbahar]. Int.J.Curr.Microbiol.App.Sci. 10(02): 1999-2007. doi: https://doi.org/10.20546/ijcmas.2021.1002.240 